\title{
Distribution of Pigeon Peas, Cassava, Coffee and Grass Roots in an Ultisol ${ }^{1,2}$
}

\author{
Edmundo Rivera, Servando Silva and José Vicente-Chandler ${ }^{3}$
}

\begin{abstract}
The distribution of roots of cassava, pigeon pea, coffee, and four grasses growing in Ultisols was studied. Cassava was the most shallow rooted of the crops with no roots extending below $105 \mathrm{~cm}$, and few below a $30-\mathrm{cm}$ soil depth. It also had the lowest density of roots at different depths. Coffee was much more deeply rooted with numerous roots down to $120 \mathrm{~cm}$, and some reaching a depth of $180 \mathrm{~cm}$. Coffee also had many more roots/L of soil at all depths than did cassava. Pigeon peas were very deep rooted with over a thousand $\mathrm{cm}$ of roots per liter of soil down to a depth of $120 \mathrm{~cm}$, and many roots down to a depth of $180 \mathrm{~cm}$. This deep rooting characteristic explains the well known resistance of pigeon pea to drought and their capacity to extract nutrients from relatively infertile soils. Guinea grass, and, to a lesser extent, Stargrass, rooted very profusely down to $180 \mathrm{~cm}$ in the soil, with guinea grass averaging over $1,000 \mathrm{~cm}$ of roots per liter of soil at all depths down to $150 \mathrm{~cm}$. The deep profuse rooting of guinea grass explains its drought resistance and its ability to outyield other grasses in the semiarid region. The data presented are important in developing recommendations for irrigating, cultivating, and fertilizing the crops studied and in determining the areas best suited to their production.
\end{abstract}

\section{INTRODUCTION}

Coffee (Coffea arabica L.) is the major export crop of the tropics, cassava (Manihot esculenta Crantz) is one of the major food crops used for local consumption in Tropical America, and pigeon peas (Cajanus cajan (L.) Millsp) is a major source of protein in India and the Caribbean countries. Tropical grasses are the basis for milk and meat production.

Information on the depth and distribution of roots of these crops is important in developing effective crop management practices. Irrigation requirements of crops depend to a great extent on the depth to which roots penetrate the soil and their density at different depths. When and how deep to cultivate the soil as well as placement and frequency of fertilization is determined by the lateral and vertical distribution of roots. Little information exists, however, other than observations and limited measurements, on the distribution and depth of roots of pigeon pea, cassava, coffee, and tropical grasses in Ultisols, which together with Oxisols constitute the major soil groups of the humid tropics.

${ }^{1}$ Manuscript submitted to Editorial Board August 18, 1982.

${ }^{2}$ This paper covers work carried out cooperatively between the Agricultural Research Service, USDA and the Agricultural Experiment Station, University of Puerto Rico, Rio Piedras, PR.

${ }^{3}$ Agronomist, Agricultural Technician, and Soil Scientist, respectively, Agricultural Research Service, USDA, Agricultural Experiment Station, University of Puerto Rico, Rio Piedras, P.R. 
The present study was conducted to determine how roots of the above mentioned crops are distributed at different soil depths in Ultisols in the humid region of Puerto Rico.

\section{MATERIALS AND METHODS}

Experiments with pigeon pea, grasses and cassava were carried out at the Corozal Substation, located at an elevation of $200 \mathrm{~m}$. Average maximum and minimum temperatures are 19 and $30^{\circ} \mathrm{C}$, respectively. Rainfall averages about $1,600 \mathrm{~mm}$ yearly and is fairly well distributed. The soil is Corozal clay (Aquic Tropudults) with $\mathrm{pH} 4.8$ and $30 \% \mathrm{Al}$ saturation of the CEC, which also contains 9 and 2 me of exchangeable $\mathrm{Ca}$ and $\mathrm{Mg}$ / $100 \mathrm{~g}$, respectively. Irrigation was applied rarely because rainfall was generally sufficient for optimum growth.

The coffee planting used was near Ciales at an elevation of $400 \mathrm{~m}$, with slightly cooler temperature than that at Corozal and similar rainfall. The soil is Humatas clay (Typic Tropohumults) with pH 5.0 and $25 \% \mathrm{Al}$ saturation of the CEC, which contains 8 and 2 me of exchangeable $\mathrm{Ca}$ and $\mathrm{Mg} / 100 \mathrm{~g}$, respectively.

Pigeon peas were planted $15 \mathrm{~cm}$ apart in rows $1 \mathrm{~m}$ apart. Four hundred fifty $\mathrm{kg}$ of 10-10-10 fertilizer per hectare was applied 3 and 10 weeks after planting. Weeds were controlled by hand weeding, and insects by periodic spraying. High yields, 9,000 kg of mature pods/ha, were produced 5 months after planting.

Cassava was planted $.3 \mathrm{~m}$ apart in rows $2 \mathrm{~m}$ apart. Five hundred $\mathrm{kg}$ of 10-5-15 fertilizer per hectare was applied 1 and 4 months after planting. Weeds were controlled by hand weeding, and insects by periodic spraying. Yields of $30,000 \mathrm{~kg}$ of edible roots per hectare were obtained 10 months after planting.

The grasses studied, [Stargrass (Cynodon nlemfuensis), Guinea grass (Panicum maximum Jacq), Caribgrass (Eriochloa polystachya H.B.K.) and Signal grass (Brachiaria brizantha (Hochst. ex A. Rich) Staph)] are among the most important and widely used throughout the tropics. The grasses had been growing for more than 5 years in well fertilized $(2,000$ $\mathrm{kg}$ of $15-5-10 / \mathrm{ha} / \mathrm{yr}$ ) intensively grazed pastures carrying 5 head/ha.

The coffee had been growing in full sunlight under intensive management for over 8 years, and received $1,500 \mathrm{~kg}$ of 10-5-15 fertilizer/ha year. Yields averaged $1,500 \mathrm{~kg}$ of market coffee/ha year.

Root distribution was studied 4 months after planting the pigeon peas, 7 months after planting the cassava, just before the coffee crop was harvested, and during a season of fast growth of the grasses.

In the study with pigeon peas and cassava blocks of soil $30 \mathrm{~cm}$ wide and $15 \mathrm{~cm}$ deep were taken $0-30$ and $30-60 \mathrm{~cm}$ from the trunks. With coffee, $30-\mathrm{cm}$-wide blocks of soil were taken at $15 \mathrm{~cm}$ depth $30 \mathrm{~cm}$ from 
the trunk. For grasses, $30 \mathrm{~cm}^{2}$ blocks of soil were taken $15 \mathrm{~cm}$ deep. Four sites were studied with each crop.

The soil was soaked in water and then the roots were carefully washed off in sieves. The length of the roots in each sample was determined by tedious, careful measurements and the results were expressed in $\mathrm{cm}$ of roots per liter $\left(1,000 \mathrm{~cm}^{3}\right)$ of soil.

Cores of undisturbed soil were taken at $30 \mathrm{~cm}$ deep at both sites, and bulk density and percentage of large pores (those drained at a tension of $60 \mathrm{~cm}$ of water) were determined with standard procedures.

\section{RESULTS AND DISCUSSION}

Table 1 shows the physical condition of the two soils at different depths. In the upper $60 \mathrm{~cm}$, the Humatas soil had a bulk density averaging

TABLE 1.-Physical condition of Corozal and Humatas clay at different depths

\begin{tabular}{cccccc}
\hline \multirow{2}{*}{$\begin{array}{c}\text { Soil depth } \\
(\mathrm{cm})\end{array}$} & \multicolumn{2}{c}{ Corozal clay } & \multicolumn{2}{c}{ Humatas clay } \\
\cline { 2 - 3 } \cline { 5 - 5 } & $\begin{array}{c}\text { Bulk } \\
\text { density }\end{array}$ & $\begin{array}{c}\text { Percent } \\
\text { large } \\
\text { pores }^{1}\end{array}$ & & $\begin{array}{c}\text { Bulk } \\
\text { density }\end{array}$ & $\begin{array}{c}\text { Percent } \\
\text { large } \\
\text { pores }^{1}\end{array}$ \\
\hline $0-30$ & 1.13 & 6.9 & 1.18 & 6.0 \\
$30-60$ & 1.29 & 3.9 & & 1.15 & 4.8 \\
$60-90$ & 1.34 & 3.0 & & 1.33 & 3.7 \\
$90-120$ & 1.29 & 4.2 & & 1.34 & 3.7 \\
$120-150$ & 1.12 & 6.1 & & 1.41 & 4.1 \\
$150-180$ & 1.17 & 4.5 & 1.35 & 3.0 \\
\hline
\end{tabular}

${ }^{1}$ Pores drained at a tension of $60 \mathrm{~cm}$ of water.

1.16 with $5.4 \%$ large pores. At greater depths, bulk density increased to an average of 1.36 and large pores decreased to about $3.6 \%$. The Corozal soil had bulk densities of about 1.14 with $6 \%$ large pores in the surface and deep layers and 1.3 and $3.7 \%$ in the 30 - to 120 -cm layers, respectively.

Figures 1 to 4 show the density of roots (cm/liter of soil) for the various crops at increasing distances from the plants and increasing depths in the soil down to a level at which no roots were found. All values are averages of those obtained at 4 sites.

Cassava was the most shallow rooted, with no roots extending below a depth of $105 \mathrm{~cm}$, and few below $30 \mathrm{~cm}$. The fleshy edible roots were all found in the upper $30 \mathrm{~cm}$. Cassava also had the lowest density of roots with only about $100 \mathrm{~cm} /$ liter of soil in the upper $30 \mathrm{~cm}$ of soil. Roots generally decreased somewhat with distance from the plant.

Coffee was much more deeply and profusely rooted than cassava, with many roots down to a depth of $120 \mathrm{~cm}$ and some down to $180 \mathrm{~cm}$. Coffee had a much greater profusion of roots at all depths than did cassava, 
with about $700 \mathrm{~cm}$ of roots/liter of soil in the $0-30-\mathrm{cm}$ layer close to the trunks. The thick anchor roots extended down to about $60 \mathrm{~cm}$.

Pigeon peas were very deep-rooted, with thousands of $\mathrm{cm}$ of roots/liter of soil down to a depth of $120 \mathrm{~cm}$, and many roots down to the $180 \mathrm{~cm}$ depth. There is no apparent explanation for the profusion of roots, exceeding $10,000 \mathrm{~cm} / \mathrm{L}$ of soil, at the $45-60 \mathrm{~cm}$ depth, a profusion which occurred at all four sites.

This deep, profuse rooting system of pigeon peas provides resistance to drought and a capacity to extract nutrients from fairly infertile soils. Lugo-López and Abrams ${ }^{4}$ (4) and Landrau and Samuels ${ }^{5}$ observed a

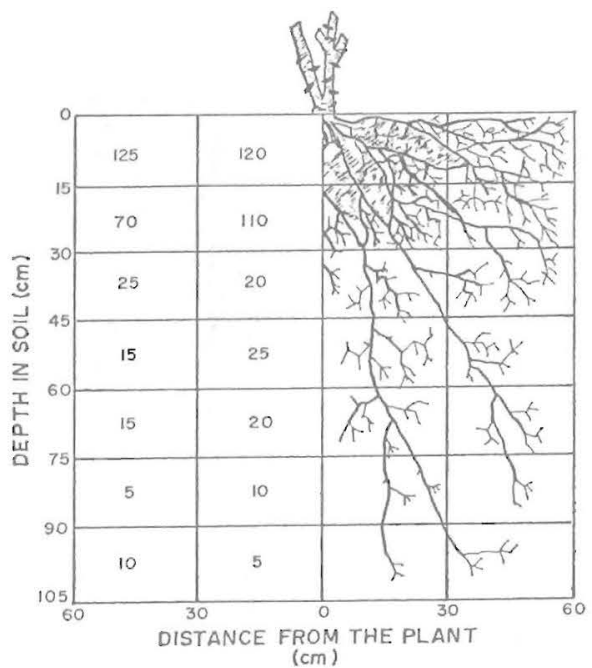

FIG. 1.-Distribution of cassava roots in an Ultisol 7 months after planting. Figures show $\mathrm{cm}$ of roots/L of soil.

general lack of response to fertilization during the first crop of pigeon peas despite the fact that the peas take up large quantities of nutrients as shown by Irizarry and Rivera ${ }^{6}$. Properly fertilized pigeon peas took up a total of $216,12,168,54$ and $19 \mathrm{~kg} / \mathrm{ha}$ of $\mathrm{N}, \mathrm{P}, \mathrm{K}, \mathrm{Ca}$ and $\mathrm{Mg}$, respectively. ${ }^{6}$

${ }^{4}$ Lugo-López, M. A., and Abrams, R., 1981. High yields of non-fertilized protein-rich pigeon peas on tropical soils of low inherent fertility in Puerto Rico: an explanation of a paradox. J. Agric. Univ. P.R. 65 (1): 21-8.

${ }^{5}$ Landrau, P. and Samuels, S., 1959. The effects of fertilizer applications on yields of pigeon peas, J. Agric. Univ. P.R. 43 (1): 69-72.

${ }^{6}$ Irizarry, H. and Rivera-Amador, E., 1983. Nutrient uptake and dry matter accumulation by intensively managed pigeon peas on a Corozal clay, J. Agric. Univ. P.R. 67 (3): 188-96. 
The four grasses studied had extensive fibrous root systems extending deep into the soil. Guinea grass, and to a lesser extent Stargrass rooted profusely down to $180 \mathrm{~cm}$. Guinea grass averaged over $1,000 \mathrm{~cm}$ of roots/ $\mathrm{L}$ of soil at all depths down to $150 \mathrm{~cm}$, and Stargrass had over $400 \mathrm{~cm}$ of roots/L of soil to a depth of $150 \mathrm{~cm}$. These data show why guinea grass is so drought resistant and yields more heavily than other grasses without

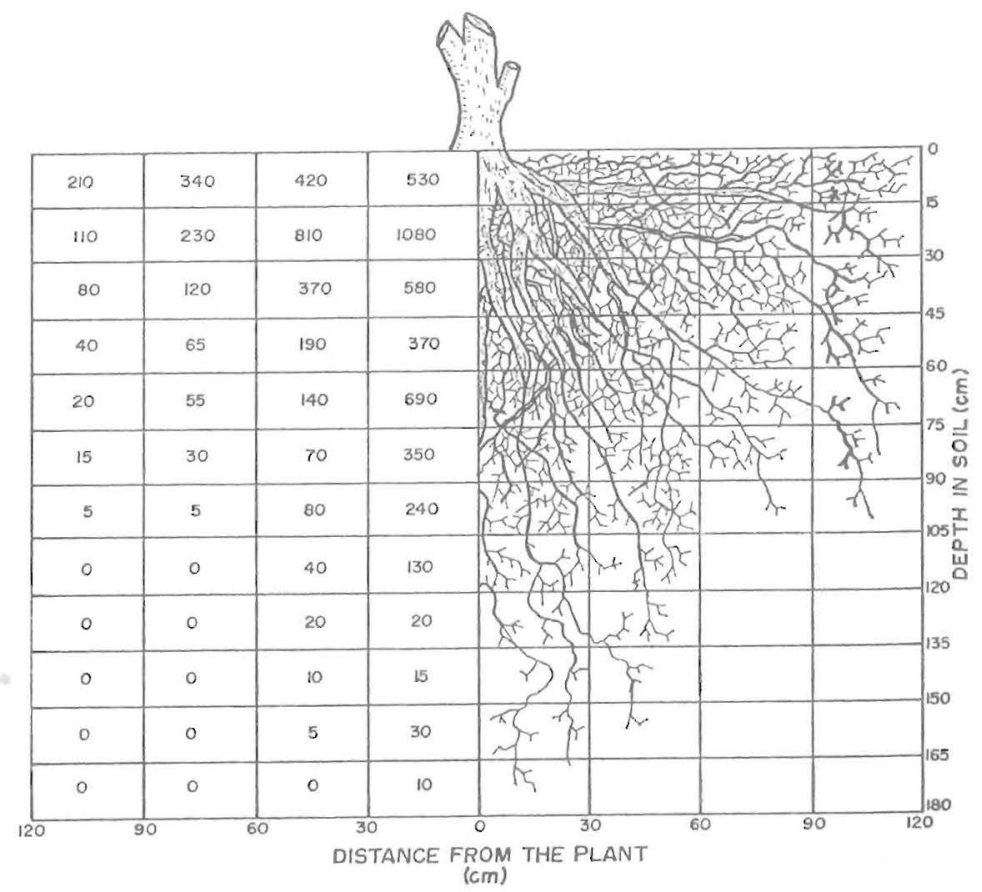

FIG. 2.-Distribution of the roots of mature intensively managed coffee growing in a Ultisol. Figures show $\mathrm{cm}$ of roots/L of soil.

irrigation in the semiarid region of Puerto Rico. Stargrass is also known to be drought tolerant once it is well established.

Caribgrass, a grass well known for its ability to do well on poorly drained, periodically flooded soils, had a less developed root system than did guinea grass or Stargrass. Signalgrass had a root system somewhere between that of caribgrass and the other two grasses.

Figure 5, taken from the work of Irizarry et al. ${ }^{7}$ shows in a study

${ }^{7}$ Irizarry, H., Vicente-Chandler, J. and Silva, S., 1981. Root distribution of plantains growing soil types, J. Agric. Univ. P.R. 65 (1): 29-34. 
carried out on Corozal clay, how shallow rooted plantains were. No roots were found below the $60-\mathrm{cm}$ depth in the soil, and fewer roots were found in the upper layer of soil than among any other of the crops studied.

The data presented are important in developing recommendations for irrigating, cultivating, and fertilizing these crops and in determining their adaptation to different ecological zones.

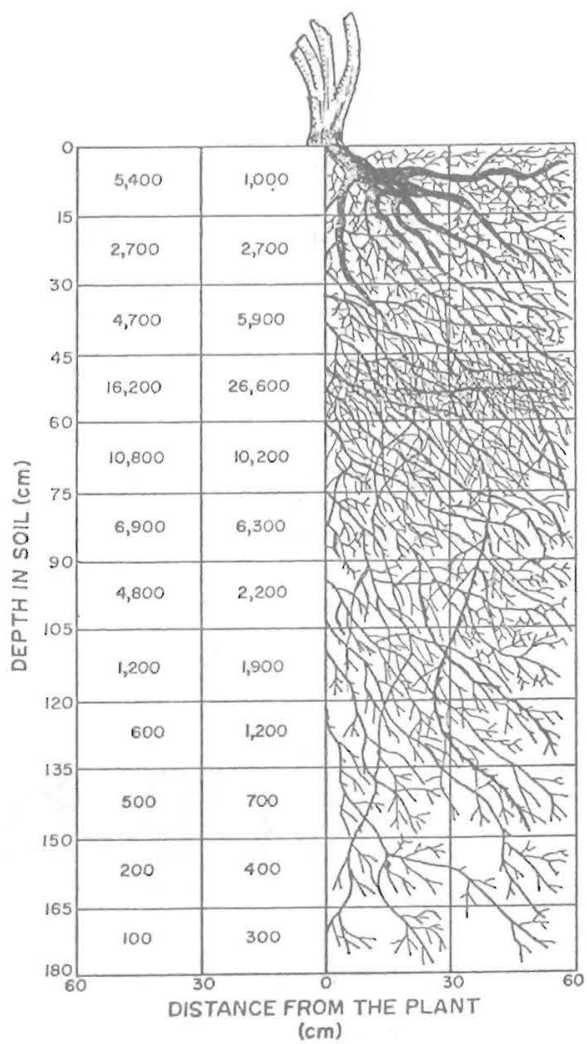

FIG. 3.-Distribution of pigeon pea roots in an Ultisol 4 months after planting. Figures show $\mathrm{cm}$ of roots/L of soil.

For example, much longer intervals can elapse between irrigations with pigeon pea or guinea grass, both of which have deep extensive root systems, than with cassava. Cassava, with a shallow poorly developed root system cannot tolerate prolonged droughts that ultimately affect yield. Guinea grass and, to a lesser extent, Stargrass can produce more forage during dry periods than can caribgrass or signalgrass, and also can survive more prolonged droughts.

Pigeon peas could be cultivated deeper and nearer the plants, without 


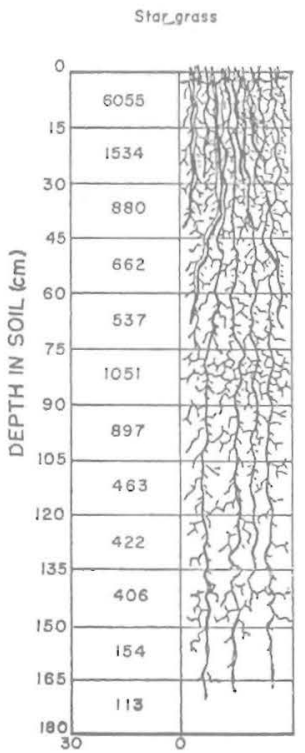

Guinea_grass

Coribgrass

Signol.grass
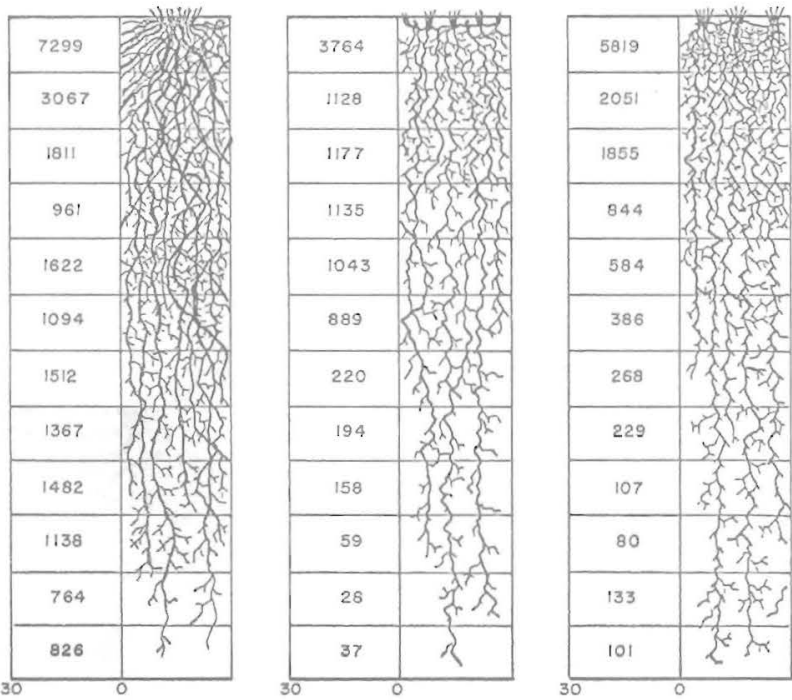

1135

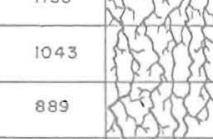

844

584

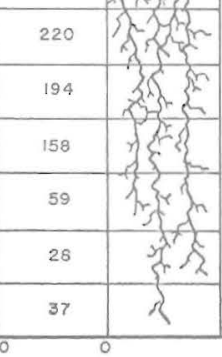

DISTANCE FROM THE PLANT

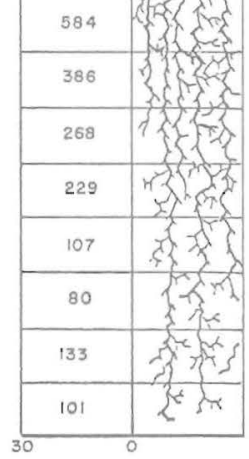

FIG. 4.-Distribution of roots of four well established grasses growing in a Ultisol. Figures show cm of roots/L of soil.

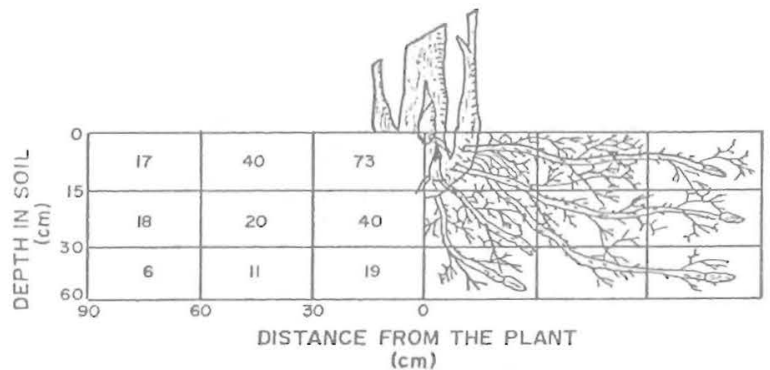

FIG. 5.-Distribution of plantain roots in an Ultisol 10 months after planting. Figures show $\mathrm{cm}$ of roots/L of soil.

greatly affecting the ability of their root system to function effectively, than could cassava, whose root system would be sharply set back by such a practice.

Also, longer intervals between fertilizer applications can be allowed for pigeon pea than for cassava because pigeon pea can take up nutrients leached to much greater soil depth, and fertilizer may be placed at some distance from the trunks because the dense root system has considerable lateral extension. 


\section{RESUMEN}

Se estudió la distribución de raíces del gandul, yuca, café y cuatro especies de yerbas forrajeras a distintas profundidades en un suelo Ultisol.

La yuca tuvo una baja densidad de raíces, las que profundizaron poco en el suelo. El cafeto desarrolló abundantes raices hasta una profundidad de $120 \mathrm{~cm}$.; algunas alcanzaron una profundidad de $180 \mathrm{~cm}$.

El gandul arraizó profusamente con más de mil $\mathrm{cm}$. de raíces por litro de suelo a profundidades hasta $120 \mathrm{~cm}$. y muchas raices alcanzaron una profundidad de $180 \mathrm{~cm}$., lo cual explica la resistencia del gandul a las sequias y su habilidad para extraer nutrimentos aun en suelos relativamente infértiles.

La yerba Guinea, y en menor grado la Estrella, desarrollaron una profusión de raíces hasta una profundidad de $180 \mathrm{~cm}$. La yerba Guinea tuvo un promedio de más de $1,000 \mathrm{~cm}$. de raíces por litro de suelo a todas las profundidades hasta $150 \mathrm{~cm}$., lo cual explica su resistencia a las sequías y su capacidad para producir más que las otras yerbas en la zona semiárida.

Estos datos son de importancia en el desarrollo de recomendaciones para regar, cultivar y abonar estas cosechas, así como para ayudar a determinar las zonas más aptas para su cultivo. 